\begin{tabular}{|c|c|c|c|}
\hline & \multicolumn{2}{|c|}{ R\&S - RESEARCH STUDIES ANATOLIA JOURNAL } & $=$ \\
\hline $\begin{array}{l}\text { Reseateh Stydies } \\
\text { Anatolia Journal }\end{array}$ & https://dergipark.org.tr/rs & Vol: 2, Issue: 5; pp: 136-148 & $=$ \\
\hline
\end{tabular}

SOCIAL AND HUMAN SCIENTIFIC

Sipahi E. (2019), "The Role of Social Work in the Context of International Development: A Cross-Country Analysis", Vol: 2 Issue: 5 ; pp: 136-148

Anahtar Kelimeler: Sosyal Hizmet, Uluslararası Keywords: Social Work, International Development,

Kalkınma, Sosyal Saglık Merkezleri Society Welfare Centers

Makale Türü Araştırma Makalesi

\title{
THE ROLE OF SOCIAL WORK IN THE CONTEXT OF INTERNATIONAL DEVELOPMENT: A CROSS-COUNTRY ANALYSIS
}

\author{
Uluslararası Kalkınma Bağlamında Sosyal Hizmetlerin Rolü: \\ Ülkeler Arası Bir Karşılaştırma \\ Esra SIPAHi *
}

\section{Geliș Tarihi / Arrived Date} 09.04.2019
Kabul Tarihi / Accepted Date 27.04.2019

\section{Yayınlanma Tarihi / Published Date} 30.04.2019

\section{öz}

Toplumdaki refah merkezleri, dünyadaki en dinamik sosyal kurumlar arasındadır. Toplum merkezleri, insanları bölgesel müdahaleye bağlı olduklarından kalkınma merkezinde tutmaktadır. Bunu yapmak için, hükümetler insanlar ve topluluklarını oluşturan çeşitli özel paydaş koalisyonları arasında kurumsal bir bağlantı sağlar. Ayrıca; sosyal, politik ve ekonomik koşulları yeniden düzenlemek için topluluk adına çeşitli sosyal değişim faaliyetlerine katılmaktadır. Dünyada sosyal hizmet uzmanları, etkili bir toplum merkezleri hareketinin birincil profesyonel liderleri olarak hizmet vermektedir. Literatür taramasinda, sosyal hizmetler ve sosyal hizmetler arasındaki ilișkileri ülkeler açısından inceleyen az sayıda çalıșma bulunmuştur. Araștırma veri toplama tekniği olarak ise çalışmada kullanılmak üzere konuyla ilgili literatür taraması yapılmış ve kitaplar, tezler, makaleler, araştırmalar ve diğer kaynaklar taranmıștır. Genel olarak uygulamalı teorik araștırma ve değerlendirme yöntemi kullanılmıștır. Ayrıca, metinlerden belge toplama, kavramsal ve mantıksal analizler yapma, karşılaștırma, anlama, analiz etme ve yorumlama, yapılarak sosyal hizmetleri geliştirmek adına çözüm odaklı öneriler sunulmaya çalışılmıştır.

$\mathrm{Bu}$ makale, çağdaș sosyal hizmet uygulamaları için yerel içeriğe katkıda bulunan küresel eğilimlerin derinlemesine bir tartışmasını sunmaktadır. Ayrıca sosyal hizmet araştırması yapılarak, sosyal hizmet eğitimi ile ilgili sonuçlar tartışılmış, sosyal hizmet uzmanlarının perspektifleri günlük uygulamalarına dahil etmeleri için bir dizi öneriler sunulmuştur.

\section{ABSTRACT}

The welfare centers in the society are among the most dynamic social institutions in the world. Community centers keep people in the center of development, as they have a commitment to regional intervention. To do this, governments provide an institutional link between people and the various private stakeholder coalitions that make up their communities. Community centers also participate in a wide range of social change activities, including advocacy with and on behalf of the community to reform basic social, political and economic conditions.

In the world, social workers serve as primary professional leaders of an effective community centers movement. In the literature review, few studies have been found which examine the relations between social services and social Works with respect to the countries. Data Collection Technique of Research; in order to be used in this study, a literature review on the subject was made, and books, theses, articles, and other resources were scanned. Generally to applied theoretical research and evaluation method to be used. In addition, collecting documents from texts, making conceptual and logical analyzes, comparing, understanding, interpreting, analyzing and interpreting as well as improving social works were tried to be used to make solution-oriented suggestions.

This article presents an in-depth discussion of global trends that contribute to local context for contemporary social work practices. In addition, the results of social work education were discussed and a number of recommendations were made for social workers to include perspectives in their daily practice.

\section{INTRODUCTION}

The practice of "community development" has always been in the conceptual center of social work practices in urban areas. The reasons for this are: 1) community work seeks to unite previously unorganized people into effective groups (e.g., improved schools, safer neighborhoods, etc.), 2) community work aims to strengthen family, kinship, and neighborly relations, and to develop new social arrangements necessary for the effective functioning of communities; and 3) community-based 
social services are one of the most effective and cost-effective approaches to serving the poor (Butcher, 1994; Goodwin, 1989; Lee, 1988; Price, 1987; Twelvetrees, 1994: UN/ESCAP, $1992 b)$.

In addition, he argues that community development is an effective component in the success of democratic societies. Community development emphasizes self-help or residents of disadvantaged communities or sectors of society. Community development, which works on behalf of disadvantaged citizens, facilitates the acquisition of resources. It is also an educational process whose purpose is to increase social and political awareness of the causes of problems and to develop the capacity of community leaders to address those problems. Community development is important in the context of social and economic change processes in a democratic society (Spergel, 1987:301).

\section{LITERATURE}

The literature examples taken in this section are the sources related to the main subject.

\subsection{History of Society Welfare Centers in The Context of Social Works}

Community welfare center work began in the early 20th century with the establishment of neighborhood centers in Europe and the United States. These studies shared their commitment to the geographical community, which is the basis of decentralized service delivery.

They also stressed the creation of partnerships to respond to the needs of the inhabitants of all communities, who are not well-off. Both working movements have given priority to working with other groups of poor and historically disadvantaged people.

In addition, the settlement house and neighborhood center work carried out a broad advocacy work on behalf of the community to achieve broader-based social reform objectives at a broader level of political organization (Taylor \& Roberts, 1985).

\subsection{About Social Work}

The impact of globalization on economic and social world population is reflected.

Social workers need to be aware of the cumulative impact of inequalities and inequities on the daily lives of individuals. This cumulative impact has been described by authors such as Krieger (2001) and Rose and Hatzenbuehler (2009) as the 'embodiment' of social class where individuals incorporate, biologically, the material and social world in which (they) live, from in utero to death; a corollary is that no aspect of our biology can be understood absent of knowledge of history and individual and societal ways of living (Krieger, 2001: 694).

Jones and Truell (2012) note that 'some social workers may question the relevance of a global agenda for practice in their setting' (p. 462) but argue that 'the dynamics of migration' where large numbers of the world's population are moving between countries to avoid poverty, civil unrest and environmental degradation mean that 'no social worker will escape the reality of globalization' (p. 462). Social work actions may be with individuals, groups and communities and in policy, advocacy and social change. In the recently developed document, Global Agenda for Social Work and Social Development Commitment to Action March 2012, the International Association of Schools of Social Work (IASSW) et al. (2012) have committed members 'to supporting, influencing and enabling structures and systems that positively address the root causes of oppression and inequality' (p. 1). Informed by such significant initiatives as the United Nations (2012) Millennium Development Goals, the Commission on Social Determinants of Health (CSDH, 2008) and the IFSW/IASSW/ICSW Global Agenda, social work practice is now also unavoidably both local and global.

\subsection{Community Centers Today}

The movement of contemporary community centers is an active and applicable force to improve the social welfare of the poor and disadvantaged in the world. Today, the movement of community centers is almost in every country and region of the world; As in the past, centers continue their commitment to social reform. Thus, community centers around the world:

1. Highlight the geographical community as the most efficient center for decentralized services (Butcher, 1994; Cnaan, 1991; McKnight, 1987; Rubin, 1986; Twelvetrees, 1994);

2. Place society in the development center in the context of social works (Chi, 1985; Pernell, 1986; Rahman, 1993; UN/ESCAP, 1992b; UNDP, 1993); 
3. Establish an institutional structure between governments and society (UN/ESCAP, 1992b; Vasoo, 1990);

4. Encourage the establishment of community partnerships to meet the needs of society (Estes, 1993a; Regab, 1981; Twelvetrees, 1994);

5. Provide a broad spectrum of material assistance to the poor (Butcher, 1994; Chi, 1985; Rahman, 1993);

6. Seek to advance the social, political, and economic rights of historically disadvantaged population groups (Campfens, 1990; Goodwin, 1989; Renshaw, 1988);

7. For people and to defend social reforms (Cnaan, 1991; Price, 1987).

The activities of community centers in the context of social works are comprehensiveand they seek to involve people, institutions and other social collectivism in complex processes that seek to improve the welfare of people at all levels of social organization.

\subsection{Social Development, Social Welfare, Social Work and Community Centers}

The movement of contemporary community centers is part of the international social development movement; it is also a complex area that involves the implementation of social, political and economic organization across all geopolitical boundaries. The aim of the social development movement is to provide at least basic social and material needs for people like social work (Estes, 1992 and 1993b).

In social work (for example, the development of antisocial work) and, accordingly, in community centers, social development differs greatly. First, the development of social work for development involves the provision of personal social work to disadvantaged people, victims of war, refugees, orphan children. Second, social workers are involved in organized efforts to help poor people remove the resources of their oppression. It aims. Social workers are also trying to accelerate the pace of social development in local communities, states and provinces, nations, regions, and ultimately the world (Estes, 1993b, 1994). Social development practice also includes efforts to promote internationally guaranteed human rights commitment, promote peace and conflict resolution, and protect the planet's fragile ecosystems (Estes, 1993b).

Social workers all over the world continue to work for a more complete realization of the profession's historical commitment to human rights (Van Soest, 1992).

\subsubsection{Social Welfare}

Ability to fully improve the efficiency of individuals and groups; It is an organized system of social services and social institutions with the aim of achieving a fulfilling life and health standards in order to reach their welfare by meeting the needs of their families and societies.

According to modern thought, the approach to human should be within a certain systematic. Identifying human needs, understanding human beings, understanding their problems and producing solutions, and integrating human as individuals must be based on a certain discipline and scientific basis. Social work is based on these ideas, philosophy and profession. In other words, social work has become visible with the functioning of the social welfare institution. (Kut, 1988, 3; Akt. Karataş and Erkan, 2002: 113).

\subsubsection{Welfare state}

It aims to eliminate the failures and inadequacies of the market economy. It is an understanding of interventionist, regulatory, redistributive and entrepreneurial state.

The welfare state has three responsibilities:

1) To guarantee a minimum income to persons and families without taking into account the market value of their assets.

2) To reduce the spread of insecurity, which will lead to personal and family problems, such as illness, old age and unemployment, if not done and by ensuring that individuals and families can overcome certain social risks. 
3) To provide the best standards for all citizens regardless of status and class within the framework of $\begin{array}{lllll}\text { generally accepted } & \text { social } & \text { 07.04.2019, }\end{array}$ https://acikders.ankara.edu.tr/course/view.php?id=639)

If a ranking is made in terms of the size of the welfare state, Sweden, Denmark and Norway's tops, USA, Australia and New Zealand is located in the bottom. England is just below the middle. In the case of prosperity models:

According to Esping ise Andersen"s current classification, the mekte model of social democratic prosperity "is above the rank- ings, followed by the in conservative prosperity model Es and the $\mathrm{tl}_{\mathrm{l}}$ liberal welfare model" at the bottom.

In researches on welfare states, devlet social welfare expenditures lem are generally taken into account in measuring and classifying these states. However, Esping ağ Andersen states that, as done in previous studies, it may be misleading to focus on social spending levels, and not fully reflect the difference in welfare states.

Table 1. Levels \& Definitions of Sed Practice in Social Work

\begin{tabular}{|c|c|}
\hline Levels of SED Practice & $\begin{array}{l}\text { Major Purposes, Outcomes, or Processes Associated With Levels of } \\
\text { International Social Work Practice }\end{array}$ \\
\hline $\begin{array}{l}\text { Individual and Group } \\
\text { Empowerment }\end{array}$ & $\begin{array}{l}\text { With strategies of ler self-help in, nasil mutual aid } 1 \text { and algla conscientious } \\
\text { dimension ekonomik, individuals and groups learn how to perceive and } \\
\text { behave the current contradictions in each society's distinct social, political } \\
\text { and economic structures. }\end{array}$ \\
\hline Conflict Resolution & $\begin{array}{l}\text { Efforts directed at reducing: } \\
\text { (1) complaints among persons or groups; } \\
\text { (2) asymmetric power relationships between members of more powerful } \\
\text { and less powerful groups. }\end{array}$ \\
\hline Institution-Building & $\begin{array}{l}\text { It expresses both the process of süre humanizing. The existing social } \\
\text { institutions and the process of establishing new institutions that respond } \\
\text { more effectively to social needs. }\end{array}$ \\
\hline Community-Building & $\begin{array}{l}\text { The process in which the society is fully aware of the social, political and } \\
\text { economic potential of participation; The process of responding to the social } \\
\text { and material needs of communities more equitably. }\end{array}$ \\
\hline Nation-Building & $\begin{array}{l}\text { The process of integrating social, political, economic and cultural } \\
\text { institutions of a society at all levels of political organization. }\end{array}$ \\
\hline Region-Building & $\begin{array}{l}\text { The process of integrating the social, political, economic and cultural } \\
\text { institutions of a region into the social organization level. }\end{array}$ \\
\hline World-Building & $\begin{array}{l}\text { The process of seeking a new system of international relations by guiding } \\
\text { for world peace search, social justice, universal satisfaction of basic human } \\
\text { needs and the protection of its ecosystem. }\end{array}$ \\
\hline
\end{tabular}

Source: Estes, 1994

\subsection{Levels of Social Development Practice}

Development-oriented community center implementation concerns people and institutions at seven levels of implementation (Table 1): Individual and group empowerment; conflict resolution; institution-building; community-building; nation-building; region-building; and world-building.

\subsubsection{Social Development-Oriented Community Center Practice}

Community centers are found throughout the world, differing in terms of local needs, available resources and training of central staff. However, wherever they are located, community centers share wider social services and social development movement; the same basic commitments to help poor people help overcome their own private resources.

\subsubsection{Latin America and Africa}

Community centers in Africa and Latin America are the primary institutions where poor people are served. The centers operate good clinics, vaccination campaigns, adult education classes, and offer family planning, nutrition, counseling, dispute resolution and other types of services. 
Community centers also help people in communities, such as community communities, health clinics, water and irrigation systems, organize community reform campaigns at local or higher political levels.

Essentially, community centers in Africa and Latin America are operated by staff with various educational and professional backgrounds, including formal education. Relatively few employees receive vocational training in human services and fewer people appreciate the broad nature of the movement of community centers in the world in the context of social development efforts in the world.

Funding in support community center activities in Africa and Latin America tends to be primary to private and civil society resources, although governments are increasingly funding the delivery of basic health and education services in rural and urban areas. However, in urban areas, governments tend to be financed more effectively by community centers.

\subsubsection{Asia}

The community center movement in Asia should be understood in terms of absolute poverty and relative weakness levels that characterize the region for most of the 20th century.

Community centers in Asia receive their funds through public resources. Similarly, the staff of Asian community centers tend to be better educated than elsewhere, and centers are organized into regional and national central coalitions.

Comparatively Asian community centers, engage in overtly political advocacy efforts with the exception of seeking to promote the establishment of new programs or services (Leung, 1990; Stone, 1989; Turner, 1993; Vasoo, 1990).

\subsubsection{Australian}

The social work profession facilitates social change, social cohesion and empowerment of people, and social development. The principles of social justice, human rights, collective responsibility and respect for diversity are important for social work. Social work, social sciences, social sciences, and social services, supported by indigenous information, occupy people and structures to address the challenges of life and to increase prosperity (IASSW, 2013).

An important element of contemporary social work is the influence of international trends on the contexts of practice. The social work profession in Australia is very diverse, but is consistent with human rights and social justice, consistent with all practices. Social workers; It works with individuals, families, groups and communities in the context of physical, social and cultural environments, past and current experiences, cultural and belief systems.

In all contexts, social workers continue to focus both on helping and improving human welfare, inequality, injustice and a dual focus on identifying and resolving any external problems that may create discrimination. Social workers can be involved in case study, counseling, advocacy, community participation and development, and social action to address both personal and social issues. Social workers also work in areas such as social justice, disadvantage, policy development, education and research.

\subsection{Soclal work services}

Common issues that social workers support others to address include:

$\begin{array}{ll}\text { - } & \text { Gambling } \\ \text { - } & \text { Pubstance abuse } \\ \text { - } & \text { Unemployment } \\ \text { - } & \text { Homelessness } \\ \text { - } & \text { Mental health issues } \\ \text { - } & \text { Physical health issues } \\ \text { - } & \text { Disability } \\ \text { - } & \text { Child and family welfare concerns }\end{array}$


- $\quad$ Family violence

- Trauma

- $\quad$ Offending behaviour

\subsection{Where do social workers work?}

Social workers work in various governmental, non-governmental and community organizations such as hospitals, community health centers, early intervention and child protection programs, family support services, schools, employment services, justice, housing, disability and elderly care services.

\subsection{Social work as a profession}

Social workers work in a variety of service areas; Child protection; child and family welfare; youth programs; Disability; health; Education; workplace; and social policy development. Since the focus of social work is very wide, from everyday life to very complex situations, practitioners are interested in all sorts of people affected by different aspects of situations.

Most social workers develop special expertise in the areas they choose to meet the social needs of employees in large companies, work with older citizens, and help communities find better ways of dealing with problems such as crime and alcohol dependence.

All social workers can help people a directly insanlar by managing organizations that serve people; It conducts research to assist other professionals or to increase the knowledge of the profession on interactions between people and society, and to help them learn better intervention ways if these processes between their environments are not realized.

\subsection{The ifsw definition of social work used in the Australian code of ethics (aasw, 2010) is:}

Social work encourages social change, problem solving in human relations and strengthening and improving human well-being. Social work, which uses social system theories, intervenes where people interact with their environment. The principles of human rights and social justice are fundamental to social work (AASW, 2010).

As part of the definition of social work, the AASW Code of Ethics (AASW, 2010) explains 'how social work operates in the interface between people and their social, cultural and physical environments' (AASW, 2010). Draws a picture of a profession that works simultaneously with many dimensions of the world, including individuals, groups, systems, communities and the natural environment. The document makes five commitments by social workers to maximize human potential and ensure prosperity. These are:

- Working with the First Peoples of Australia;

- Work with and support people to achieve the best levels of social welfare;

- Trying to address and compensate for injustice and injustice affecting the lives of customers, customer groups and socially disadvantaged people;

- Trying to achieve human rights and social justice through social development, systemic change and ethical behavior of research (AASW, 2010).

\subsubsection{The Pacific}

Almost all humanitarian services in the Pacific region are provided through community welfare centers (UNDP, 1993). Most of these centers are funded by non-governmental organizations.

Most centers are organized to provide concrete services to people. Some help build local public health clinics and schools, while some offer job training courses to workers. Centers often serve as community meeting sites, voting sites, and in some places as adult education centers. Family planning services and catering services are also available in community centers. Community centers in the Pacific are organized along village and tribal lines, and so governance and policy-making are handled by traditional institutions. However, community centers often serve as important links between people and governments for higher levels of political organization. 


\subsubsection{New Zealand}

New Zealand, Maori (the indigenous people of New Zealand) and non-Maori have great gaps in life. They rose from a gap of 7-8 years in the early 1980s to a range of 10 years in the 1990s in the 1990s, but since about 7-8 years since. Mortality rates for Maori are two to three times the proportion of nonMaori in middle age, including the causes of integrated and cardiovascular diseases (Blakely and Simmers, 2011).

The different socioeconomic position among the groups explains about $50 \%$ of the ethnic differences in health. Health inequalities appear very early in life and can be seen for the most common causes of death, injury or hospitalization. For example, in New Zealand, Maori babies are more than five times more likely to die than Sudden Infant Death Syndrome compared to non-Maori babies and six times more likely to sleep with bronchiolitis in infants living in the poorest neighborhoods (Blakely and Simmers, 2011). Suicide rates tend to be highest amongst young people, Maori, and those living in deprived areas and the prevalence of mental health issues is much higher for Maori and Pacific people (Blakely and Simmers, 2011).

\subsubsection{Poverty in the Developed and the Developing World}

\subsection{Canada and the United States}

For people from low socioeconomic groups in developed countries, for example, in Canada and the United States, especially those living in poverty, there are similar cases for low-income people with disadvantageous elements. In the United Kingdom, the Gypsy and Traveler families reflect similarly poor results compared to the wider population (Cemlyn, 2008). There are also inequalities in societies in different stages of economic and social development.

In poorer countries, such as Cambodia and Lao People's Democratic Republic, the life expectancy of adult males is comparable to 57 to 62 years, compared to more wealthy countries such as Japan, Singapore, New Zealand and Australia. 79 - 80 years (Asia Pacific Global Action for Health Equality Network (HealthGAEN), 2011).

Paying attention to the economic well-being of societies and individuals is one of the cornerstones of the social and social justice principles of social services, as reflected in the basic values and principles of social work (NASW, 2008). Social workers were trained professionally to see their customers as individuals, families, organizations and communities working in different settings. Based on a strong intervention-based approach, social workers strongly believe in the capacity and potential of change at both the personal and community level. (Saleebey, 1997).

\section{RESEARCH}

\subsection{Aim of Research}

Aim of the study; The aim of this study is to investigate the national and international social development in the context of International Development through the contribution of social studies to community centers and community center work.

\subsection{Method of Research}

In the literature review, few studies have been found which examine the relations between social services and social services with respect to the countries. In this respect, the article is important. Data Collection Technique of Research: In order to be used in this study, a literature review on the subject was made, and books, theses, articles, research and other resources were scanned. Generally to applied theoretical research and evaluation method to be used. In addition, collecting documents from texts, making conceptual and logical analyzes, comparing, understanding, interpreting, analyzing and interpreting as well as improving social works were tried to be used to make solutionoriented suggestions.

\subsection{Importance of Research}

In the literature review, few studies have been found which examine the relations between social services and social services with respect to the countries. In this respect, the article is important. 


\section{THE FUNCTIONS OF SUPERVISION}

Social work supervision is an integral part of the social service profession's approach to implementation. According to Kadushin (1985), professional control in social work and social welfare has three functions:

-Educator: to improve the knowledge and skills of stakeholders; gain professional qualification; reflective application;

-Administrative / managerial: promoting and maintaining positive working standards; implementation of agency policies; monitoring and improving business performance;

-Support: to ensure compatible business relationships, motivation and job satisfaction.

Figure 1. Health and Social Problems are Worse in More Unequal Countries.

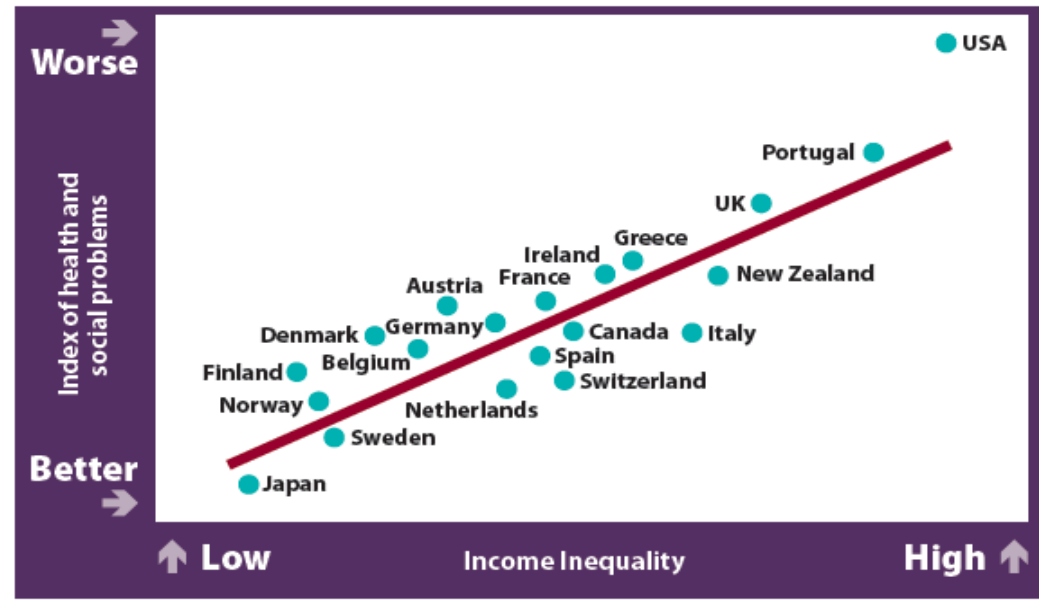

(Note: the above uses the ratio of income between the top and bottom $20 \%$ of income after tax as a measure of inequality, but other measures produce similar results).

Source: Reproduced with permission from Wilkinson and Pickett (2009: 174).

(Figure 1 from the Equality Trust depicting the relationship between inequality and an aggregate measure of health and social problems).

It may be statistically difficult to demonstrate the relationship between international inequalities, violent conflicts, environmental pollution, or a lack of ability to progress from a poor country to a more developed country. A clear example of international inequality is the export of environmental impacts from developed countries to developing countries. Most of the use of natural resources such as timber and minerals is carried out in less developed countries with landscaping at lower wages. This has the advantage of permitting less expensive goods and allowing the developed country to avoid influencing their environment and allow consumption to effectively export the environmental impacts.

The term report inequalities (refers to the final report of CSDH (2008), led by Professor Sir Michael Marmot, used to describe measurable differences in the health characteristics of individuals. The report states that the source of health inequality originates from the unequal distribution of power, income, goods and services globally and nationally. In the immediate and visible circumstances of people's lives, injustice provides access to health services, schools and education, work and leisure situations, homes, community towns and cities, and the chance to live a thriving life.

Mackenbach (2012) identified paradoxical findings between social state models and social state who states that karşıllı health inequalities are not systematically smaller in Scandinavian countries, contrary to expectations sistematik, indicating the existence of inequalities and inequalities. The editor states that a broad literature review by Beckfield and Krieger (2009) shows that ve the relationship between the welfare regime and the magnitude of health inequality is optimally inconsistent.

In a forward-looking proposal, Mackenbach offers to go back to analyzing certain determinants and the social provisions undertaken to address them. Using the example of the effects of unemployment on the health of a country's individual programs to support the unemployed through various welfare 
and social programs examined. Similarities in the context of social services of this observation and the differences emphasize the complexities and uncertainties of these relations.

\section{COMPARISON OF WELFARE STATE}

Table 2. Different Welfare Spending Policy Practices in Countries

\begin{tabular}{|l|l|l|}
\hline \multicolumn{1}{|c|}{ Source } & \multicolumn{1}{|c|}{ Country } & \multicolumn{1}{c|}{ For Example } \\
\hline $\begin{array}{l}\text { (Hinrichs, } \\
\text { 1992). }\end{array}$ & ABD & $\begin{array}{l}\text { It is the first example of the liberal system, which investigates money } \\
\text { and property aid and is a form of welfare state where there is a } \\
\text { strong class difference between welfare recipients and others, and } \\
\text { the market has a strong role in the creation of welfare in this system. }\end{array}$ \\
\hline (Cox, 2001) & GERMANY & $\begin{array}{l}\text { The welfare state, the welfare state, which protects social rights and } \\
\text { the welfare state in which the aid is not very relevant, is one of the } \\
\text { first examples of the conservative system, which protects the status } \\
\text { quo, includes redistributive, solid social plans and social } \\
\text { commitments that protect the traditional family. }\end{array}$ \\
\hline $\begin{array}{l}\text { (Thakur v.d., } \\
\text { 2007) }\end{array}$ & SWEDISH & $\begin{array}{l}\text { It is a welfare state that considers medium-class aid as a right to } \\
\text { finance a high number of aids and to consider full employment as a } \\
\text { necessity. }\end{array}$ \\
\hline
\end{tabular}

* Source: Table 2: The results of the literature review were created by the researcher.

Even in developed countries, there may be different welfare practices. Indeed, based on Germany, Denmark and the Netherlands are also undergoing major reforms. Social Welfare Expenditures in the Welfare State in Increasing Globalization international competition stipulates the restructuring of the welfare state in Germany (Cox, 2001: 496).

There is no single model for the social role of the state. Each society develops its own model according to current ideology, values, financial capacity and social needs of citizens. Of course, the current role of the state is directly related to the investments and policies pursued over the past 50 years. The main problem here is how to achieve success in the past to facilitate and sustain the future prosperity of individuals. A proposed solution here is the optimal mix between responsibilities of state, market, family and society (Maxwell, 2003: 9).

Especially in recent times, the major social transformations have fundamentally changed the needs of people (Maxwell, 2003: 9).

The future social and economic welfare concept depends on the expectations of the individuals in the developed countries and their capacity to take measures towards them (Maxwell, 2003: 10).

\section{RESULT}

Personnel engaged in social service activities in developing countries; At the local level, social workers may be active participants in the professional interest groups who are connected to global health networks and movements that aim to address health inequalities and act on the social determinants of health. Concepts such as organization can help social workers in understanding the cumulative impact of intergenerational poverty and social impoverishment.

In routine practice, social workers should consider how the local context of their practice is affected.

Economic factors, privatization and commodification with wider social and global trends health services, environmental degradation, climate change, political, civil unrest and violence. These includes are:

These factors affect their actions and priorities and their interest in social services.

Social work practice in health should include a holistic and perfect focus on individual and broad social contexts. Therefore, it is not enough to teach policies supporting economic equality and material welfare. However, social workers should constantly participate in legislation and programs at national, state and local level to identify resources and barriers, to improve financial capacity and welfare to work in communities. 
Regional community centers continue to serve as one of the most effective institutional resources to promote large-scale social, political and economic development. Community centers have been shown to be particularly effective in reaching poor and other historically disadvantaged population groups, including women and children, the elderly, chronic patients and non-permanent residents. Community centers are considered to be highly effective organizations to assist groups of persons deprived of their rights to help them engage in collective action towards the elimination of sources of deprivation.

Indeed, recent declarations and decisions by the United Nations and other international development aid organizations highlight the contribution of community centers to reducing poverty, promoting public participation, and achieving full social justice. Community centers have been particularly effective in delivering more intensive health, education and other humanitarian services to scattered groups of people and those living in urban slums and other poorer areas. Most centers integrate the service with some vocational training and research criteria, thus contributing to the preparation of new generation service providers that serve people in their region.

Indeed, community centers offer a sosyal natural environment bir for social work practices; in essence they combine "social" with "personal" in social work practices. The community center work also provides important links to developmental social workers with colleagues working in other countries and regions of the world. With the globalization process, socio-economic problems are increasing more rapidly than ever. The rapid globalization of the economy creates winners on the one hand and losers on the other hand, but the plurality of losers in developed countries endangers the continuity of globalization. The increasing distribution of unjust welfare on a global scale jeopardizes stability and trust in the world, social peace corrupts. There is an intense debate on the future of social welfare services and the future of rising costs in the whole world. There are doubts about the sustainability of social security systems, problems related to unemployment, poverty and poverty (beggars, street gangs, homeless, increasing crime rates, increasing violence, commoditization, organ trafficking etc.) and the feeling that many people will be more uncertain in their future welfare. Reduced protection against rising risks and weakening of the welfare state affect the poorest.

Demographic changes in labor markets, social relations and family life necessitate reform in welfare states.

The 21st century has new opportunities, but there is no doubt that it comes with serious new economic and social problems. Global integration should therefore not only focus on economic wealth, but also to provide an adequate standard of living and social service to all citizens on a global scale, to guarantee a constant equality between citizens and to achieve equality in employment and full employment.

\section{REFERENCES}

Asia Pacific Global Action for Health Equality Network. (2011).

Bowles, W., Collingridge, M., Curry, S., \& Valentine B. (2006). Ethical Practice in Social Work an Applied Approach, Crows Nest NSW: Allen and Unwin.

Butcher, Hugh et al. (1994) .Community and Public Policy (London: Pluto Press).

Bywaters P., E. McLeod and Napier L. (2009). Social Work and Global Health Inequalities: Practice and Policy Developments, Bristol: Policy Press.

Bywaters, P., S. Cowden, E. McLeod, S. Rose and G. Singh. (2009). 'Integrating Health Inequalities in Social Work Learning and Teaching', Social Work and Policy Digest Southampton: Higher Education Academy and SWAP.

Campfens, H. (1990). Issues in Organizing Impoverished Women in Latin America. Social Development Issues 13(1).

Chi Yue C. (2017). Language and Social Behavior. Columbia University and The University of HongKong.

Cnaan, R. A., \& Goldberg-Glen, R. S. (1991). Measuring Motivation to Volunteer in Human Services. Journal of Applied Behavioral Science, 27(3), 269-284. 
Commission on Social Determinants of Health (CSDH). (2008). Closing the Gap in a Generation: Health Equity through Action on the Social Determinants of Health, Geneva: World Health Organization.

Cox, H.R. (2001). The Social Costruction of an Imperative Why Welfare Reform Happened in Denmark and the Netherlands but not in Germany. World Politics.

Estes R. (1992). Developmental Social Work: A New Paradigm for a New Century.

Estes R. (1993). A Century of Social Work and Social Welfare at Penn.

Estes R. (1994). Social work, social development and community welfare centers in international perspective. University of Pennsylvania School of Social Work.

Fortune, A. E., \& Abramson, J. S. (1993). Predictors Of Satisfaction With Field Practicum Among Social Work Students, Clinical Supervisor.

Giddings, M. M., Vodde, R., \& Cleveland, P. (2003). Examining Student-Field Instructor Problems in Practicum: Beyond Student Satisfaction Measures, Clinical Supervisor, 22(2), 191-214.

Goodwin C, (1987), "Unilateral Departure", In Talk and Social Organisation (Graham Button, John R E Lee, eds.), Clevedon, England, Multilingual Matters, pp. 206-216.

Harold E. Smoke Price. (1987). The Human Side of Technology: A Panel, Proceedings of the Human Factors and Ergonomics Society Annual Meeting.

Hinrichs, K. (1992). Reviewed work(s): The Three Worlds Of Welfare Capitalism By Gøsta EspingAndersen. European Sociological Review, Vol. 8, No. 2. (Sep.), 200- 202.ss.

Hugman, R. (2005). New Approaches in Ethics for the Caring Professions. Houndmills: Palgrave Macmillan.

Jones, D. N., \& Truell, R. (2012). The Global Agenda for Social Work and Social Development: A Place to Link Together and be Effective in a Globalized World. International Social Work, $55(4), 454-472$.

Kadushin, A. (1985). Supervision in Social Work (2nd ed.). New York: Columbia University Press.

Krieger N, Davey Smith G. Re. (2000). Seeking Causal Explanations in Social Epidemiology' (letter). Am J Epidemiol.

Kut, Sema. (1983). Sosyal Hizmet Eğitiminde 22 Yıl. Hacettepe Üniversitesi Sosyal Hizmetler Yüksekokulu Dergisi, Cilt 1, Sayı 1, ss.1-12

Leung, Joe. (1990). The Community-Based Welfare System in China, Community Development J 25(3):195-205.

Mackenbach JP, Kulhánová I, Bopp M, Deboosere P, Eikemo TA, Hoffmann R, Kulik MC, Leinsalu M, Martikainen P, Menvielle G, Regidor E, Wojtyniak B, Ostergren O, Lundberg O; for the EUROGBD-SE Consortium. (2015). Variations in the Relation Between Education and CauseSpecific Mortality in 19 European Populations: A Test of the Fundamental Causes" Theory of Social Inequalities in Health. Social Science \& Medicine,127:51-62.

Maxwell S. (2003). Food Policy Old and New Development Policy Review, Published by Blackwell. $21(5-6): 531-553$

McKnight, J. L. (1987). Regenerating Community, Social Policy .17(3):54-58.

Pernell, Ruby B. (1986). Empowerment and Social Group Work, Innovations in Social Group Work: Feedback from Practice to Theory (NY: The Haworth Press), pp. 107-118.

Rahman, A. (1993). People's Self-Development: Perspectives on Participatory Action Research. London: Zed Books.

Richard J. (1997). Estes, Social Work, Social Development, And Community Welfare Centers in International Perspective, International Social Work.

Regab, A. et al. (1981). Representation in Neighborhood Organizations, Social Development Issues 5:62-73 
Renshaw, Judy et al. (1988). Care in the Community: The First Steps (London: Gower Publishing).

Rose S., Hatzenbuehler S. (2009). Embodying Social Class: The Link Between Poverty, Income Inequality and Health. International Social Work, 52, 459-471.

Rubin, Herbert and Irene Rubin. (1986). Chapter 1, The Goals of Community Organizing (Columbus: Merrill Publishing Company), pp. 3-19; Chapter 2, The Components of Community Development (Columbus: Merrill Publishing Company), pp. 20-43.

Saleebey, D. (1997). The Strengths Perspective in Social Work Practice (2nd ed.). White Plains, NY: Longman.

Spergel, Irving A. (1987). Community Development in Encyclopedia of Social Work, 18th Edition, Volume 1 (Silver Springs MD: National Association of Social Workers), pp. 299-308.

Stone, Linda. (1989). Cultural Crossroads of Community Participation in Development: A Case From Nepal, Human Organization 48(3):206-213.

Taylor, Samuel H. and Robert Roberts. (1985). Theory and Practice of Community Social Work (New York: Columbia University Press).

Thakur, S., Keen, M., Horváth, B., Cerra, V. (2007). Sweden's Welfare State.

The International Association of Schools of Social Work (IASSW) et al. (2012).

The International Association of School of Social Work. (2013).

Turner, John E. (1993). Villages Astir: Community Development, Tradition and Change in Korea (Westport CT: Praeger).

Twelvetrees, Alan (Ed.). (1994). Community Economic Development in the UK and the USA (London: Pluto Press).

UN/ESCAP. (1992a). Proceedings of the Fourth Asian and Pacific Ministerial Conference on Welfare and Social Development. (Bangkok: UN), ST/ESCAP/1070.

UN/ESCAP. (1992b). A Social Development Strategy for Asia and the Pacific: Toward the Year 2000 and Beyond. (Bangkok: UN/ESCAP), ST/ESCAP/1170.

UNDP. (1993). Published for the United Nations Development Programme (UNDP) New York, Oxford University.

UN/ESCAP. (1992a). Proceedings of the Fourth Asian and Pacific Ministerial Conference on Welfare and Social Development. (Bangkok: UN), ST/ESCAP/1070.

UN/ESCAP. (1992b). A Social Development Strategy for Asia and the Pacific: Toward the Year 2000 and Beyond. (Bangkok: UN/ESCAP), ST/ESCAP/1170.

Van Soest, D. (1992). Incorporating Peace and Social Justice Into the Social Work Curriculum (Washington: National Association of Social Workers).

Vasoo, S. (1990). Studying Neighbourhood Leaders' Participation in Resident's Organizations in Hong Kong and Singapore: Some theoretical perspectives International Social Work 33:107120.

Watson, D., Clark, L. A., \& Tellegen, A. (1988). Development and Validation of Brief Measures of Positive and Negative Affect: The PANAS Scales. Journal of Personality and Social Psychology, 54(6), 1063-1070.

Wilkinson, R. and K. Pickett. (2009). The Spirit Level: Why Equality is better for Everyone. London: Penguin.

\section{INTERNET RESOURCES}

Australian Association of Social Workers. (2008). Australian Social Work Education and Accreditation Standards. Canberra: AASW, www.aasw.asn.au/publications/ethics-andstandards (Date of access 04 April 2019).

Australian Association of Social Workers. (2010). Code of Ethics. Canberra: AASW. Retrieved from AASW, www.aasw.asn.au/publications/ethics-and-standards (Date of access 04 April 2019). 
Blakely, T. and D. Simmers. (2011). Fact and Action Sheets on Health Inequities. Public Health Association New Zealand. Available online at: http://www.pha.org.nz/documents/fact-actionhealth-inequalities.pdf (Date of access 05 March 2019).

Can the Bumblebee Keep Flying?. (2003). International Monetary Fund, May 1, 2003,

http://www.imf.org/external/pubs/nft/2003/sweden/index.htm (Date of access 06 April 2019).

Council on Social Work Education (2008). Educational Policy and Accreditation Standards. Retrieved from http://www.cswe.org/Accreditation/2008EPASDescription.aspx (Date of access 03 April 2019).

http://www.who.int/social determinants/thecommission/finalreport (Date of access 01 April 2019).

National Association of Social Workers (NASW) (2008). Code of Ethics of the National Association of Social Workers: Ethical Principles. Washington, DC: Author. Retrieved from http://www.socialworkers.org/code.asp (Date of access 05 April 2019).

National Association of Social Workers (NASW). (2011). Retrieved from http://www.naswdc.org/practice/default.asp (Date of access 05 March 2019). 